\title{
Unilateral Relapsing Primary Angiitis of the CNS
}

\section{An Entity Suggesting Differences in the Immune Response Between the Cerebral Hemispheres} Mahmoud A. AbdelRazek, MD,* James M. Hillis, MBBS,* Yanjun Guo, MD,* Maria Martinez-Lage, MD,
Taha Gholipour, MD, Jacob Sloane, MD, PhD, Tracey Cho, MD, and Marcelo Matiello, MD

Neurol Neuroimmunol Neuroinflamm 2021;8:e936. doi:10.1212/NXI.0000000000000936

\section{Abstract}

\section{Objective}

To determine whether studying patients with strictly unilateral relapsing primary angiitis of the CNS (UR-PACNS) can support hemispheric differences in immune response mechanisms, we reviewed characteristics of a group of such patients.

\section{Methods}

We surveiled our institution for patients with UR-PACNS, after characterizing one such case. We defined UR-PACNS as PACNS with clinical and radiographic relapses strictly recurring in 1 brain hemisphere, with or without hemiatrophy. PACNS must have been biopsy proven. Three total cases were identified at our institution. A literature search for similar reports yielded 4 additional cases. The combined 7 cases were reviewed for demographic, clinical, imaging, and pathologic trends.

\section{Results}

The median age at time of clinical onset among the 7 cases was 26 years (range 10-49 years); 5 were male (71\%). All 7 patients presented with seizures. The mean follow-up duration was 7.5 years (4-14.1 years). The annualized relapse rate ranged between 0.2 and 1. UR-PACNS involved the left cerebral hemisphere in 5 of the 7 patients. There was no consistent relationship between the patient's dominant hand and the diseased side. When performed (5 cases), conventional angiogram was nondiagnostic. CSF examination showed nucleated cells and protein levels in normal range in 3 cases and ranged from 6 to 11 cells $/ \mu \mathrm{L}$ and 49 to $110 \mathrm{mg} / \mathrm{dL}$ in 4 cases, respectively. All cases were diagnosed with lesional biopsy, showing lymphocytic type of vasculitis of the small- and medium-sized vessels. Patients treated with steroids alone showed progression. Induction therapy with cyclophosphamide or rituximab followed by a steroid sparing agent resulted in the most consistent disease remission.

\section{Conclusions}

Combining our 3 cases with others reported in the literature allows better clinical understanding about this rare and extremely puzzling disease entity. We hypothesize that a functional difference in immune responses, caused by such discrepancies as basal levels of cytokines, asymmetric distribution of microglia, and differences in modulation of the systemic immune functions, rather than a structural antigenic difference, between the right and left brain may explain this phenomenon, but this is speculative.

\author{
Correspondence \\ Dr. AbdelRazek \\ mabdelrazek@mah.harvard.edu
}




\section{Glossary}

ABRA = amyloid beta-related angiitis; AED = antiepileptic drug; DWI = diffusion-weighted imaging; PACNS = primary angiitis of the CNS; UR = unilateral relapsing; VZV = Varicella zoster virus; $\mathbf{W B C}=$ white blood cell.

Primary angiitis of the CNS (PACNS) was first recognized in 1959 and is characterized by idiopathic inflammation of arteries of the brain, spinal cord, and leptomeninges. ${ }^{1}$ The size of the afflicted vessels carries significant diagnostic and prognostic consequences. Disease of predominately smalland medium-sized vessels is often missed by CT angiography, magnetic resonance angiography, and conventional angiography and rather diagnosed with brain biopsy. In such cases, small infarctions are more typical and are associated with a more favorable prognosis overall. Angiitis of large-sized vessels is more likely to have diagnostic angiographic findings and leads to large territorial infarctions and a less favorable prognosis. ${ }^{2}$ Our understanding is limited regarding the factors that lead to this difference in the size of the afflicted vessels between different individuals.

Despite the well-known functional differences between the right and left hemispheres of the brain, studies identifying the transcribed RNA in different regions of the brain do not demonstrate a significant difference in gene expression between the 2 hemispheres. ${ }^{3}$ Moreover, evidence of asymmetries of total arterial supply between the right and left brain is, similarly, lacking. ${ }^{4}$ These data render a readily available explanation for chronic or relapsing asymmetric brain disease difficult to ascertain. In large case series reporting on PACNS, relapsing vasculitis in only 1 hemisphere is not described. ${ }^{2,5}$ Salavarani et al. reported unilateral findings in $8.8 \%$ of patients diagnosed by brain biopsy and in $11.5 \%$ of patients diagnosed by angiogram, but did not identify whether further relapses continued to focus on the same hemisphere. ${ }^{2}$

Here, we report the diagnostic approach, clinical course, and treatment of 3 cases of unilateral relapsing PACNS (URPACNS). In addition, we review the literature and summarize the previously reported cases. We also explore how this disease entity can indicate hemispheric differences in immune response mechanisms.

\section{Methods}

The index case (case 1) was identified through its presentation in our institution's (Massachusetts General Hospital, Boston) weekly neuroimmunology faculty meeting. At that time, other colleagues (M.M., J.M.H. and Y.G.) present at that meeting identified the similar presentation of the patients (cases 2 and 3 ) who they were following clinically. We queried our Research Patient Data Registry to search for additional patients with UR-PANCS within the last 5 years (January 2015-December 2019). Although 145 patients (53.7\% female; average age 54.3, SD 16.9) were seen at Massachusetts General Hospital for suspected cerebral vasculitis, during that time, we did not identify any additional UR-PACNS cases. In our search, UR-PACNS was defined as biopsy-proven PACNS with $\geq 2$ relapses after the initial onset, strictly confined to 1 cerebral hemisphere, with or without relative atrophy of that hemisphere. Relapses were defined as a new clinical neurologic manifestation with brain MRI demonstrating at least 1 new lesion with gadolinium enhancement. If there was no gadolinium enhancement, a relapse could still be recorded if it had been judged by the clinician to be so. We identified 3 such patients, described below in detail. To further characterize this entity, we performed an indexed literature search through PubMed for similar reports using the key words "unilateral, unihemispheric, PACNS, vasculitis, and angiitis" and their synonyms in varying combinations. The references within the identified publications were also reviewed for pertinent studies. This resulted in 4 additional cases. $^{6-9}$ The 7 cases were combined to review demographic, clinical, imaging, and pathologic trends.

\section{Data Availability}

Upon appropriate request, the corresponding author can provide deidentified data, e.g., normal serum and CSF tests.

\section{Standard Protocol Approvals, Registrations, and Patient Consents}

The authors received written informed consent for research publication from the 3 patients included in the study.

\section{Case Descriptions}

\section{Case 1}

A 23-year-old right-handed Caucasian woman with a history of migraine headaches and cocaine and alcohol abuse presented in April 2003 with a generalized tonic-clonic seizure. This also coincided with an increased frequency and severity of her headaches. Her migraine history started at age 13 years and was consistent with sporadic hemiplegic migraine, where headaches were associated with transient $(\sim 2$ hours) weakness of the right arm and leg. Her MRI (4/2003) showed strictly left hemispheric multiple periventricular and deep white matter T2 hyperintense foci, some with faint contrast enhancement (figure 1, A and B) without diffusion-weighted imaging (DWI) changes. CSF analysis was normal without oligoclonal bands. EEG showed intermittent left temporal slowing in the theta and delta range, but no epileptiform activity. She was started on antiepileptic drug (AED) therapy, eventually accumulating 3 AEDs over the course of 4 years for both nonepileptic and 17 epileptic events characterized as 


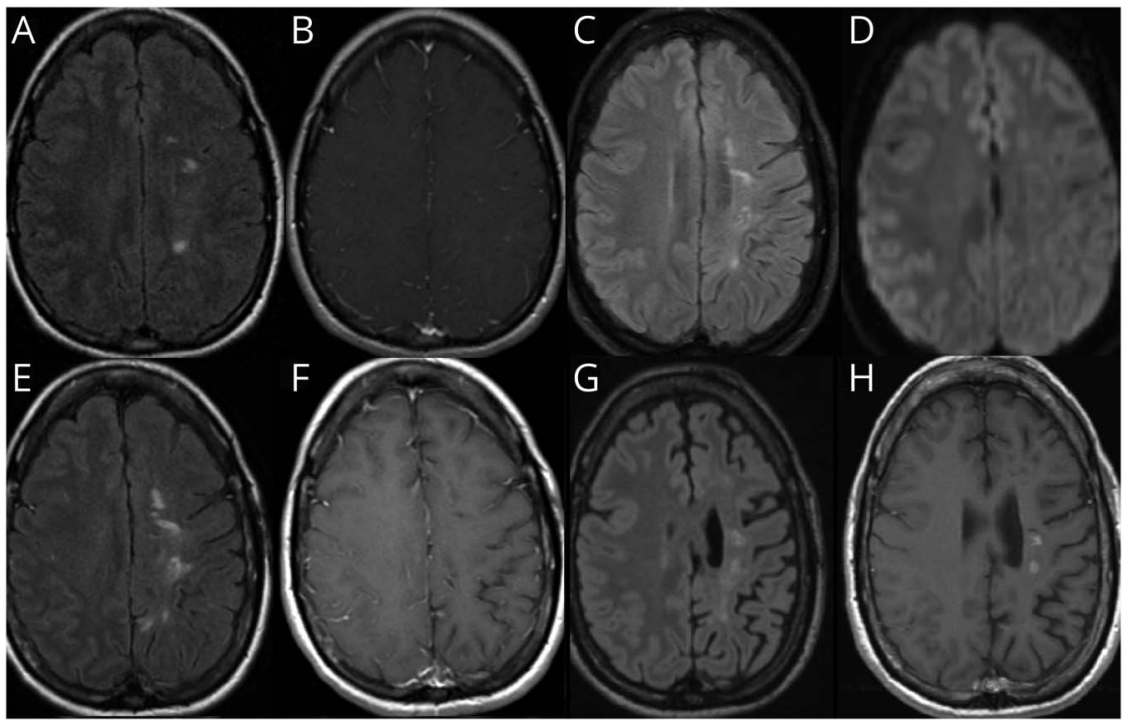

(A) Fluid-attenuated inversion recovery (FLAIR) and (B) T1 postcontrast sequences at presentation demonstrating strictly unilateral subcortical lesions with subtle contrast enhancement. (C) FLAIR sequence 4 years and 8 months after presentation, showing the first indication of volume loss in the afflicted left hemisphere despite developing no new discrete lesions since presentation and no change in the previous foci of subcortical disease. (D) Diffusionweighted imaging throughout her clinical course has not shown significant restricted diffusion. (E and G) FLAIR and ( $\mathrm{F}$ and $\mathrm{H}$ ) T1 postcontrast sequences showing new T2 lesions on FLAIR with $(H)$ and without $(F)$ corresponding gadolinium enhancement. ( $E$ and $F$ ) are 6 years and 4 months after presentation, whereas ( $G$ and $H$ ) are 13 years and 3 months after presentation, and all demonstrate progression of unilateral brain atrophy.

right arm tonic partial onset seizures with secondary tonicclonic generalization. Five years after presentation, her neurologic examination was only remarkable for slightly slowed finger-tap speed and alternating movements with the right hand. A formal neuropsychiatric evaluation showed lownormal performance in the executive function and language domains. She was on 1 AED with good seizure control but without a formal diagnosis.

Over the course of the 14 years following her initial presentation, she had 11 more brain MRIs exhibiting progressive unihemispheric atrophy, and a total of 3 clinical relapses associated with new gadolinium-enhancing T2 lesions. All relapses presented clinically with focal or generalized seizure and headache. The first occurred 6 years and 4 months after presentation (figure 1, E and F), and she was started on mycophenolate mofetil for presumed CNS vasculitis without angiographic or pathologic confirmation. The second occurred 7 years and 3 months after presentation; AED regimen was adjusted. Mycophenolate was discontinued 12 years after presentation, which was followed by the third relapse occurring 13 years and 3 months after presentation (figure 1, G and $\mathrm{H})$. Cerebral angiogram was normal, but lesional biopsy showed nongranulomatous, non-necrotizing lymphocytic vasculitis (figure 3). Mycophenolate was restarted, and she received 2 cycles of rituximab $1 \mathrm{~g}$ infusions (6 months apart). She has had no further relapses until her last follow-up 14 years after presentation, at which point her neurologic examination was not significantly changed from that documented above, 5 years after presentation. Additional studies included 2 further unremarkable CSF studies ( 5 years and 13 years 3 months after presentation), unremarkable MRI of the cervical and thoracic spine (3 years from presentation), and serum autoimmune and genetic testing (table 1$)$.

\section{Case 2}

A 19-year-old left-handed Caucasian woman presented with a secondarily generalized tonic-clonic seizure that commenced with focal right lower extremity numbness and paresthesia. Brain MRI demonstrated left frontal and parietal multifocal cortical and subcortical T2 hyperintense lesions with contrast enhancement (figure 2, A and B). CSF analysis showed lymphocytic pleocytosis (white blood cell [WBC] 8 cells $/ \mu \mathrm{L}$; 93\% lymphocytes, 6\% monocytes, and 1\% polymorphonuclear cells) and positive CSF oligoclonal bands. She had weakly positive serum antinuclear antibody (1:40). Her laboratory values were otherwise unremarkable (table 1). She was commenced on levetiracetam $500 \mathrm{mg}$ twice daily. One month later, she developed episodes of right upper and lower extremity numbness and paresthesia lasting up to 3 hours. Brain MRI demonstrated interval progression of patchy nodular enhancement within the left cerebellar hemisphere and interval growth of a rounded lesion within the left mesial temporal lobe. She was treated with IV methylprednisolone $1,000 \mathrm{mg}$ daily for 3 days. At follow-up 2 months later, there was interval improvement of symptoms and lesions on brain MRI, although small residual foci of enhancement remained (figure 2, C and D).

Ten months after initial presentation, she developed a prolonged episode of right-sided numbness. Brain MRI showed enhancing lesions in the left temporal, frontal, and parietal lobes. Her dose of levetiracetam was increased to $750 \mathrm{mg}$ twice daily. Twelve months after presentation, she underwent brain biopsy that demonstrated inflammatory and reactive changes, as well as a necrotic focus, consistent with small vessel lymphoplasmacytic vasculitis (figure 3). She was commenced on prednisone $60 \mathrm{mg}$ daily for 6 weeks followed by taper and mycophenolate 
Table 1 Clinical Features

\begin{tabular}{|c|c|c|c|c|c|c|c|}
\hline & $\begin{array}{l}\text { 1: } 2002 \text { Derry } \\
\text { et al. } 6\end{array}$ & $\begin{array}{l}\text { 2: } 2009 \\
\text { Damasceno } \\
\text { et al. }{ }^{7}\end{array}$ & $\begin{array}{l}\text { 3: } 2011 \text { Ho } \\
\text { et al. }{ }^{8}\end{array}$ & $\begin{array}{l}4: 2016 \text { Johnson } \\
\text { et al. } 9\end{array}$ & $\begin{array}{l}\text { 5: } 2020 \\
\text { AbdelRazek } \\
\text { et al. \#1 }\end{array}$ & $\begin{array}{l}\text { 6: } 2020 \\
\text { AbdelRazek } \\
\text { et al. \#2 }\end{array}$ & $\begin{array}{l}\text { 7: } 2020 \\
\text { AbdelRazek } \\
\text { et al. \#3 }\end{array}$ \\
\hline $\begin{array}{l}\text { Age at } \\
\text { clinical } \\
\text { onset/sex/ } \\
\text { race }\end{array}$ & $10 / \mathrm{M}$ & $35 / \mathrm{M}$ & 49/M/Hispanic & $30 / \mathrm{M}$ & 23/F/Caucasian & 19/F/Caucasian & 26/M/Chinese \\
\hline Handedness & No mention & Right & No mention & Right & Right & Left & Right \\
\hline $\begin{array}{l}\text { Follow-up } \\
\text { duration, y }\end{array}$ & 11.75 & 10 & 4 & 4 & 14.1 & 4 & 5 \\
\hline $\begin{array}{l}\text { Presenting } \\
\text { symptoms }\end{array}$ & $\begin{array}{l}\text { L focal motor } \\
\text { seizure, } L \\
\text { hemiparesis, and } \\
\text { R-sided } \\
\text { headache }\end{array}$ & $\begin{array}{l}\text { Generalized } \\
\text { seizure, R } \\
\text { hemiparesis, } \\
\text { and } \\
\text { expressive } \\
\text { aphasia }\end{array}$ & $\begin{array}{l}\text { R focal seizure, } \\
\text { R hemiparesis, } \\
\text { and aphasia }\end{array}$ & $\begin{array}{l}\text { R hemiparesis, } \\
\text { hemianopia, } \\
\text { nonfluent aphasia, } \\
\text { and seizures }\end{array}$ & $\begin{array}{l}\text { Generalized } \\
\text { tonic-clonic } \\
\text { seizure }\end{array}$ & $\begin{array}{l}\text { R focal seizure } \\
\text { with } \\
\text { secondarily } \\
\text { generalized } \\
\text { tonic-clonic } \\
\text { seizure }\end{array}$ & $\begin{array}{l}\text { Generalized } \\
\text { tonic-clonic } \\
\text { seizure }\end{array}$ \\
\hline $\begin{array}{l}\text { Treatments } \\
\text { and } \\
\text { responses }\end{array}$ & $\begin{array}{l}\text { Deteriorated on } \\
\text { dexamethasone; } \\
\text { stable on CYC }\end{array}$ & $\begin{array}{l}\text { Failed } \\
\text { steroids, } \\
\text { azathioprine, } \\
\text { and beta- } \\
\text { interferon 1a }\end{array}$ & $\begin{array}{l}\text { Steroids and } \\
\text { CYC very } \\
\text { successful with } \\
\text { near-complete } \\
\text { resolution }\end{array}$ & $\begin{array}{l}\text { Pulse steroids, CYC/ } \\
\text { rituximab induction } \\
\text { and MPM } \\
\text { maintenance } \\
\text { controlled disease for } \\
4 \text { y }\end{array}$ & $\begin{array}{l}\text { Relapse on } \\
\text { MPM, followed } \\
\text { for } 1 \text { y on } \\
\text { rituximab } \\
\text { without relapse }\end{array}$ & $\begin{array}{l}\text { Steroids, MPM } \\
\text { largely } \\
\text { successful }\end{array}$ & $\begin{array}{l}\text { Deteriorated } \\
\text { on pulse } \\
\text { steroids and } \\
\text { stable for } 1 \text { y } \\
\text { on MPM }\end{array}$ \\
\hline $\begin{array}{l}\text { Eventual } \\
\text { cognitive } \\
\text { deficits }\end{array}$ & No & $\begin{array}{l}\text { Yes (aphasia } \\
\text { and problem } \\
\text { solving) }\end{array}$ & No & $\begin{array}{l}\text { Yes (moderate } \\
\text { nonfluent aphasia) }\end{array}$ & $\begin{array}{l}\text { Low-normal } \\
\text { executive } \\
\text { function and } \\
\text { language } \\
\text { domains }\end{array}$ & No & $\begin{array}{l}\text { Mild (MMSE } \\
30 \text { and MoCA } \\
262 \text { y after } \\
\text { onset) }\end{array}$ \\
\hline $\begin{array}{l}\text { Eventual } \\
\text { motor } \\
\text { deficits }\end{array}$ & L hemiplegia & $\mathrm{R}$ hemiparesis & No & Mild R hemiparesis & No & No & $\mathrm{R}$ hemiparesis \\
\hline $\begin{array}{l}\text { Eventual } \\
\text { sensory } \\
\text { deficits }\end{array}$ & Hemianopia & No mention & No mention & No mention & No & No & No mention \\
\hline $\begin{array}{l}\text { Seizure is } \\
\text { the } \\
\text { presenting } \\
\text { symptom }\end{array}$ & Yes & Yes & Yes & $\begin{array}{l}\text { Yes (first seizure } \\
\text { during the first } \\
\text { hospitalization) }\end{array}$ & Yes & Yes & Yes \\
\hline $\begin{array}{l}\text { Headache } \\
\text { with } \\
\text { relapses }\end{array}$ & Yes & No mention & Yes & Yes & Yes & No & No \\
\hline $\begin{array}{l}\text { No. of } \\
\text { relapses }\end{array}$ & At least 3 & At least 3 & At least 4 & At least 3 & 3 & At least 4 & 4 \\
\hline $\begin{array}{l}\text { Annualized } \\
\text { relapse rate }\end{array}$ & 0.26 & 0.3 & 1 & 0.75 & 0.21 & 1 & 0.8 \\
\hline
\end{tabular}

Abbreviations: CYC = cyclophosphamide; MMSE = Mini-Mental State Examination; MoCA = Montreal Cognitive Assessment; MPM = mycophenolate mofetil.

$1,000 \mathrm{mg}$ twice daily. Her dose of levetiracetam was also increased to $1,000 \mathrm{mg}$ twice daily postoperatively for worsening right-sided numbness. Four years after initial presentation, she has not had new symptoms or worsening on MRI. She remains on the same therapeutic regimen and continues to have occasional focal seizures.

\section{Case 3}

A healthy 26-year-old right-handed Chinese man presented to the emergency department in March 2012 with generalized tonic-clonic seizure after an aura of abnormal vision as if witnessing a 3D movie. Brain MRI showed patchy T2 lesions in the right temporal and occipital lobes with multiple nodular and patchy areas of enhancement. CT angiogram of the head was unremarkable apart from showing a common blood supply to both thalami (artery of Percheron). Lumbar puncture opening pressure was $105 \mathrm{mmH}_{2} \mathrm{O}$, with mild pleocytosis $(8 \mathrm{WBC} / \mu \mathrm{L})$ and normal protein $(44 \mathrm{mg} / \mathrm{dL})$. Autoimmune encephalitis and ganglioside spectrum antibody panels of CSF were negative. CSF immunoglobulin G index was 0.96 (normal 0.32-0.6). Cryptococcus, cysticercosis antibody, Mycobacterium tuberculosis PCR, and bacteria were not detected in CSF. Other normal serum tests are summarized in table 1 . 


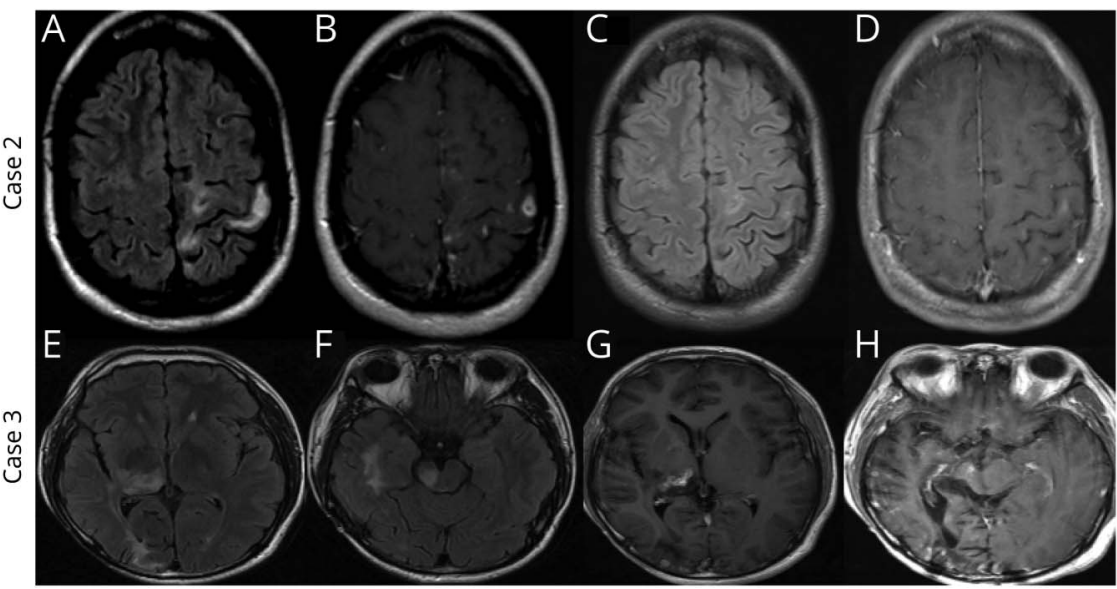

(A) Fluid-attenuated inversion recovery (FLAIR) and (B) T1 postcontrast sequences at presentation demonstrating left frontal and parietal multifocal cortical and subcortical T2 hyperintense lesions with contrast enhancement. (C) FLAIR and (D) T1 postcontrast sequences 2 months after treatment with IV pulse glucocorticoid therapy (3 months after presentation) demonstrating near resolution of the previously described lesions, although some T2 hyperintensity and contrast enhancement remain. ( $E$ and F) FLAIR and (G) T1 postcontrast sequences 14 months after presentation demonstrating T2 hyperintensity in the right thalamus, occipital lobe, temporal lobe, and midbrain with enhancing lesions in right thalamus and occipital lobe cortex. (H) T1 postcontrast sequence during a relapse 4 years 2 months from onset demonstrating numerous gadolinium-enhancing lesions in the right occipital and temporal cortex and in the right anterior midbrain and displaying significant hemiatrophy of the right hemisphere of the brain. Diffusion-weighted imaging sequences showed no significant changes in both cases.

Ten months after presentation, he gradually developed numbness in his left upper limb. Thirteen months after presentation, his left upper and lower limbs were weak. He could not hold light objects. When walking, he felt as if his left lower limb was treading on cotton. He was admitted to a hospital in Beijing, China. Examination showed reduced muscle tone of left upper limb. His left hand showed weakness and incoordination described as thalamic hand. Distal muscle strength of the left upper limb was $4 / 5$, and proximal was $5-/ 5$; the left lower limb was $4 / 5$ proximally and distally. Hoffman sign was present in both hands, and his left toes showed positive Puusepp sign. Brain MRI, 14 months after presentation, showed radiographic progression with patchy $\mathrm{T} 2$ lesions in the right thalamus, temporal lobe, frontal lobe, occipital lobe, basal ganglia region, midbrain, and pons. Multiple nodular and patchy enhancement signals were seen in the right cerebral hemisphere. Brain MRI 3 months later (17 months after presentation) showed further progression with all lesions, old and new, remaining strictly confined to the right hemisphere (figure 2, E-G). Lesional biopsy from the superficial right occipital lobe of about $1.5 \mathrm{~cm}$ block of subcortical, cortical, and leptomeningeal tissue was performed. Clinical pathologic diagnosis of primary angiitis of the CNS was made (figure 3 ). The patient was commenced on methylprednisolone pulse therapy $1,000 \mathrm{mg} / \mathrm{d}$ for 5 days with subsequent oral taper. Despite this, he continued to have gradual clinical and radiographic progression.

Four years and 2 months after initial presentation, his left arm and leg strength had deteriorated further with worsened spasticity. He complained of cognitive deficits, although his Mini-Mental State Examination was 30/30, and Montreal Cognitive Assessment was 26/30. Brain MRI showed further progression with new lesions in the right thalamus, midbrain, upper pons, temporal lobe, occipital lobe, frontal lobe, and basal ganglia region. There was significant atrophy of the right hemisphere and right brainstem (figure $2 \mathrm{H}$ ). There were new enhancing lesions in the left thalamus. Immunosuppressive therapy with mycophenolate $200 \mathrm{mg}$ twice daily was prescribed accompanied with prednisone $8 \mathrm{mg}$ daily. Ten months later ( 5 years after presentation), the follow-up brain MRI showed stability with no new lesions, although significant unilateral brain atrophy including the brainstem remained evident.

\section{Results}

In addition to the 3 cases we present in this report, there have been 4 prior distinct case reports of biopsy-proven URPACNS $^{6-9}$ in patients aged $10,30,35$, and 49 years at the time of clinical onset (table 1). Although 2 case series from one academic center reported on unilateral intracranial arteriopathy in 93 children, ${ }^{10,11}$ the disease entity described in these pediatric neurology case series differs from UR-PACNS. These reports describe a largely transient monophasic arteriopathy. In the first report, only 5 of 79 children had relapsing arteriopathy, and only 1 of these 5 remained unilateral at follow-up and was thought to be related to neuroborreliosis and not PACNS. ${ }^{10}$ In the second report, none of the 14 cases with unilateral arteriopathy had a relapse after a median 8.8year follow-up and appeared to be monophasic in character. ${ }^{11}$

\section{Demographics, Clinical Course, and Response to Therapy}

In the 7 cases that have been reported to date, 3 of whom from this study, the median age at time of clinical onset was 26 years (range $10-49$ years); 5 were male ( $71 \%)$; the mean follow-up duration was 7.5 years (4-14.1 years); the mean annualized relapse rate was $0.62(0.2-1)$, defined as the average number of clinical relapses with new MRI changes per year. All 7 patients presented with seizures; this is likely related to the small caliber size of the inflicted blood vessels, which tend to 

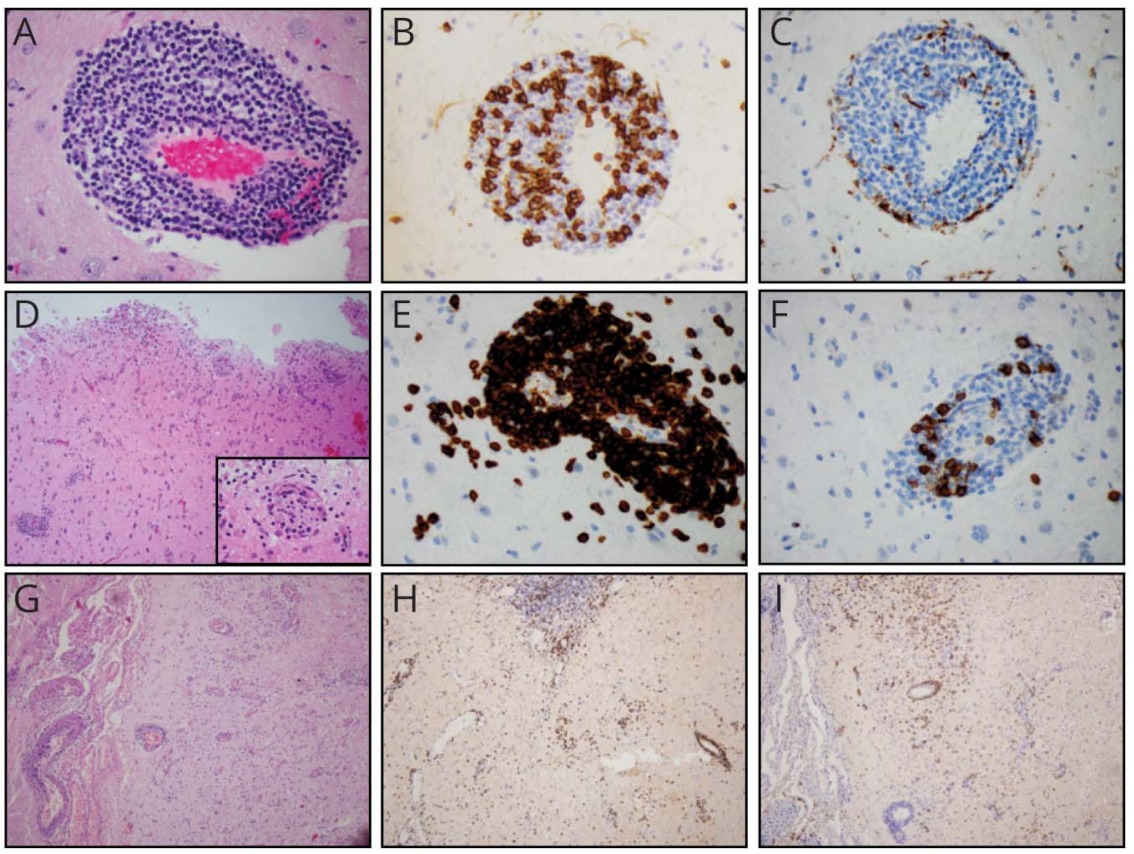

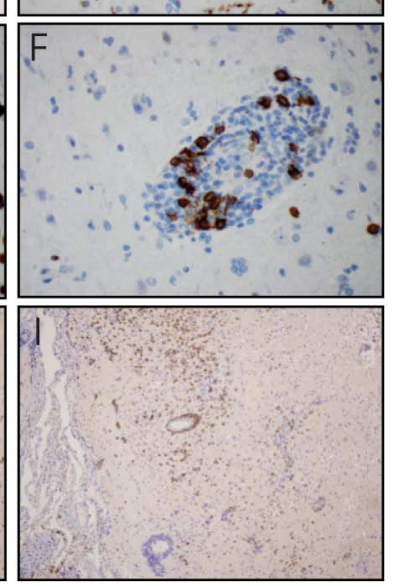

Findings were similar in all 3 patients, consisting of varying amounts of perivascular and parenchymal chronic inflammation, tissue necrosis, and reactive gliosis. Small sized vessels demonstrated transmural inflammation, but fibrinoid necrosis was not a prominent finding. No granulomas or microglial nodules were identified. Microscopic examination for Case 1 demonstrated multifocal perivascular inflammatory infiltrates $(A, H \& E, \times 400)$ composed of mature lymphocytes, many of which were CD8 ${ }^{+}$ $T$ cells $(B, C D 8 I H C, \times 400)$, rare plasma cells, and some macrophages (C, CD68 IHC). Similar perivascular inflammatory infiltrates were seen in Case 2 , with more prominent spillage into the adjacent parenchyma $(D, H \& E, \times 100)$, with occasional obliterated vessels ( $D$ insert, $H \& E, \times 400$ ) and focal tissue necrosis (not shown). Most inflammatory cells were also T cells $(E, C D 3 I H C, \times 400)$, with scattered $B$ cells $(F, C D 20 I H C, \times 400)$. Case 3 demonstrated inflammatory infiltrates within the vascular walls of medium-sized leptomeningeal vessels in addition to small-sized parenchymal vessels $(G, H \& E, \times 100)$, composed of many $T$ cells $(H, C D 3 I H C, \times 100)$ with an additional component of plasma cells (I, CD138 $\mathrm{IHC}, \times 100)$. The lack of leptomeningeal involvement in Cases 1 and 2 however may be due to limited sampling with a smaller biopsy size in comparison with Case 3. In all cases, there were no histopathologic findings to suggest any process different from PACNS. $\mathrm{H} \& \mathrm{E}=$ hematoxylin and eosin; $\mathrm{IHC}=$ immunohistochemistry; PACNS = primary angiitis of the CNS. be cortical and thus more likely to induce seizure activity. Two of the cases presented with focal unilateral arm and leg convulsions without generalization; in 3 cases, there was associated aphasia; and 4 had hemiparesis not related to Todd paralysis at presentation. Throughout their clinical course, all patients had several clinical and radiographic relapses, 4 patients with headache as a prominent feature, which is the most common symptom in PACNS, occurring in $60 \%$ of cases. ${ }^{2}$ At the end of the reported follow-up duration, 4 patients had cognitive deficits (language and problem solving), 3 patients had hemiparesis, and 1 had hemiplegia and hemianopia without a deficit in cognition.

The 7 patients varied in response to immunomodulatory therapy as detailed in table 1. Cyclophosphamide and rituximab were successful in suppressing disease relapses whenever used (4 of the 7 cases). Patients who did not receive early induction therapy with these high-potent immunosuppressants showed disease progression. Mycophenolate mofetil was successful as maintenance therapy when it was used after induction therapy in 2 cases. Whenever steroids were used alone, disease was not controlled.

\section{Neuroimaging}

Conventional cerebral angiogram was performed in 4 of the 7 cases and did not show evidence of vasculitis. Conversely, all cases were diagnosed due to recurring parenchymal disease on brain MRI leading to a diagnostic brain biopsy. This suggests that the target in this disease entity is the involvement of small- and medium-sized vessels rather than large-sized vessels. This also explains the presentation of the 7 cases with seizures, a cortical epiphenomenon more likely to occur with distal vasculitis. Of interest, 2 patients showed asymmetry of the caliber size of the intracranial vessels, one on conventional angiogram and the other on magnetic resonance angiogram. All patients showed recurring gadolinium-enhancing strictly unilateral lesions. In the 3 cases we present, none had DWI restricted diffusion, whereas in the prior 4 cases, there was no specific comment on this. In case 3, only, there was infratentorial involvement, above the level of fiber decussation. This case also showed contralateral thalamic involvement late in the disease, which we believe was related to the common vasculature of both thalami, artery of Percheron, seen on CT angiogram. Table 2 summarizes neuroimaging findings.

In 4 of the 7 cases, there was progressive unilateral volume loss such as that seen in Rasmussen encephalitis, including the midbrain in 1 patient (case 3 of this report). We note that early induction therapy with a strong immunosupressant was absent in these cases. One case had evidence for subtle volume loss between onset and the first radiographic disease relapse ( 2 years and 9 months apart), which may indicate subclinical baseline chronic inflammation affecting that single hemisphere with superimposed acute inflammatory episodes causing clinical relapse (case 1 of this report).

\section{Laboratory Investigations}

Extensive workup for systemic markers of infectious or autoimmune/rheumatologic disease was unremarkable in all patients. The specific workup in each case differed, outlined in 
Table 2 Laboratory and imaging features

\begin{tabular}{|c|c|c|c|c|c|c|c|}
\hline & $\begin{array}{l}\text { 1: } 2002 \text { Derry } \\
\text { et al. } 6\end{array}$ & $\begin{array}{l}\text { 2: } 2009 \\
\text { Damasceno } \\
\text { et al. }{ }^{7}\end{array}$ & $\begin{array}{l}\text { 3: } 2011 \text { Ho } \\
\text { et al. }{ }^{8}\end{array}$ & $\begin{array}{l}4: 2016 \text { Johnson } \\
\text { et al. }{ }^{9}\end{array}$ & $\begin{array}{l}\text { 5: } 2020 \\
\text { AbdelRazek } \\
\text { et al. \#1 }\end{array}$ & $\begin{array}{l}\text { 6: } 2020 \\
\text { AbdelRazek } \\
\text { et al. \#2 }\end{array}$ & $\begin{array}{l}\text { 7: } 2020 \\
\text { AbdelRazek } \\
\text { et al. \#3 }\end{array}$ \\
\hline CSF analysis & $\begin{array}{l}\text { Positive OCB, } \\
\text { protein } 110 \\
\text { mg/dL, } \\
\text { otherwise } \\
\text { normal }\end{array}$ & $\begin{array}{l}6 \mathrm{WBC} / \mu \mathrm{L} \text { no } \\
\mathrm{OCB}, \text { protein } \\
68 \mathrm{mg} / \mathrm{dL}, \\
\text { and negative } \\
\text { VZV DNA }\end{array}$ & Unremarkable & $\begin{array}{l}11 \mathrm{WBC} / \mu \mathrm{L}, 87 \% \\
\text { lymphocytes, protein } \\
50 \mathrm{mg} / \mathrm{dL}, 2 \text { OCBs, and } \\
\text { negative DNA for VZV, } \\
\text { HSV, EBV, and CMV }\end{array}$ & $\begin{array}{l}\text { Normal WBC, } \\
\text { protein. } \\
\text { Immunostain } \\
\text { on brain biopsy } \\
\text { for VZV is } \\
\text { negative. }\end{array}$ & $\begin{array}{l}\text { Positive OCB, } 6 \\
\text { WBC/ } \mu \mathrm{L}, 96 \% \\
\text { lymphocytes, } \\
\text { protein } 49 \mathrm{mg} / \mathrm{dL} \text {, } \\
\text { and negative VZV } \\
\text { DNA }\end{array}$ & $\begin{array}{l}8 \mathrm{WBC} / \mu \mathrm{L} \\
\text { and protein } \\
44 \mathrm{mg} / \mathrm{dL}\end{array}$ \\
\hline $\begin{array}{l}\text { Conventional } \\
\text { angiogram } \\
\text { diagnostic of } \\
\text { vasculitis } \\
\text { (other } \\
\text { angiography } \\
\text { done) }\end{array}$ & $\begin{array}{l}\text { No (although } \\
\text { showed R MCA } \\
\text { and its } \\
\text { branches of } \\
\text { smaller caliber } \\
\text { than L) }\end{array}$ & No & $\begin{array}{l}\text { No (but } \\
\text { showed L MCA } \\
\text { and R MCA } \\
\text { aneurysms) }\end{array}$ & $\begin{array}{l}\text { No mention (MRA } \\
\text { showed small caliber } \\
\text { of R MCA, ACA, and } \\
\text { PCA compared with L) }\end{array}$ & No & $\begin{array}{l}\text { Not performed } \\
\text { (although CTA } \\
\text { head and neck } \\
\text { normal) }\end{array}$ & $\begin{array}{l}\text { Not } \\
\text { performed } \\
\text { (CTA normal, } \\
\text { artery of } \\
\text { Percheron } \\
\text { seen) }\end{array}$ \\
\hline $\begin{array}{l}\text { Parenchymal } \\
\text { lesion vascular } \\
\text { distribution }\end{array}$ & R MCA and PCA & $\begin{array}{l}\text { L MCA and } \\
\text { ACA at least }\end{array}$ & L MCA & L MCA and PCA & L MCA & $\begin{array}{l}\text { L ACA, MCA, and } \\
\text { PCA }\end{array}$ & $\begin{array}{l}\text { R MCA and } \\
\text { PCA }\end{array}$ \\
\hline $\begin{array}{l}\text { Gadolinium } \\
\text { enhancement }\end{array}$ & Yes & Yes & Yes & Yes & Yes & Yes & Yes \\
\hline $\begin{array}{l}\text { Lesion DWI } \\
\text { positivity }\end{array}$ & No mention & No mention & No mention & No mention & No & No & No \\
\hline $\begin{array}{l}\text { Hemiatrophy } \\
\text { on follow-up } \\
\text { MRI }\end{array}$ & Yes & Yes & No & No & Yes & No & Yes \\
\hline $\begin{array}{l}\text { Pathologic } \\
\text { variant }\end{array}$ & Lymphocytic & Lymphocytic & Lymphocytic & Lymphocytic & Lymphocytic & Lymphocytic & Lymphocytic \\
\hline $\begin{array}{l}\text { Inflamed artery } \\
\text { caliber }\end{array}$ & Small & Small & Small & Small and medium & Small & Small & $\begin{array}{l}\text { Small and } \\
\text { medium }\end{array}$ \\
\hline $\begin{array}{l}\text { Diagnosis made } \\
\text { by biopsy or } \\
\text { angiogram }\end{array}$ & $\begin{array}{l}\text { Lesional } \\
\text { biopsy }\end{array}$ & $\begin{array}{l}\text { Lesional } \\
\text { biopsy }\end{array}$ & $\begin{array}{l}\text { Lesional } \\
\text { biopsy }\end{array}$ & Lesional biopsy & Lesional biopsy & Lesional biopsy & $\begin{array}{l}\text { Lesional } \\
\text { biopsy }\end{array}$ \\
\hline
\end{tabular}

Abbreviations: $A C A$ = anterior cerebral artery; $C M V=$ cytomegalovirus; $C T A=C T$ angiography; DWI = diffusion-weighted imaging; EBV = Epstein-Barr virus; $\mathrm{HSV}=$ herpes simplex virus; MCA = middle cerebral artery; MRA = magnetic resonance angiography; OCB = oligoclonal band; PCA = posterior cerebral artery; VZV = varicella zoster virus; $\mathrm{WBC}=$ white blood cell.

table 2. Noteworthy, CSF examination was overall unremarkable or mildly abnormal. Nucleated cells and protein levels were normal in 3 cases ( $<6$ cells $/ \mu \mathrm{L}$ and $<46 \mathrm{mg} / \mathrm{dL}$ ) and ranged from 6 to 11 cells $/ \mu \mathrm{L}$ and 49 to $110 \mathrm{mg} / \mathrm{dL}$ in the remaining 4 cases, respectively. Oligoclonal bands were mentioned to be positive in 3 cases. Varicella zoster virus (VZV) PCR from CSF was reported to be negative in 3 cases, and immunostaining for VZV on the brain biopsy was negative in a fourth case.

\section{Neuropathology}

All 7 cases were diagnosed as PACNS by brain biopsy. Two cases had a nondiagnostic first brain biopsy, one on presentation with a positive biopsy 3 years later, and the second 6 years into the disease with a positive biopsy 2 years after that. The pathologic findings in all 7 cases were consistent with lymphocytic vasculitis of the small- and medium-sized vessels, without evidence of granulomatous or significant vessel wall necrotizing components. In our 3 cases, the most salient finding was transmural and perivascular inflammation, with evidence of ischemic injury from small vessel involvement, most prominent in case 2 (figure 3). No particular finding on biopsy explained the unilateral nature of the vasculitis. Amyloid staining was not performed in any case, likely given the young age (under 50 years) in all patients, the absence of granulomatous changes in all cases, which amyloid betarelated angiitis (ABRA) classically shows, and that ABRA almost exclusively occurs in older patients. VZV immunohistochemical stain was performed in 2 cases (cases 1 and 2) and was negative.

\section{Discussion}

The most striking feature of these patients' presentation was the laterality of their clinical and neuroimaging findings. Although the occurrence of lesions in 1 hemisphere repeatedly may be due to chance, not only did patients have multiple relapses in only 1 hemisphere but also most of the relapses had multiple lesions. For example, in case 3 of this article, 
there were at least 10 new enhancing lesions over the course of 4 relapses; thus, the chance of random lateral occurrence would be 0.001 (using the formula $0.5^{\mathrm{n}}$ where $\mathrm{n}=$ number of lesions). Similar statistical chance was demonstrated in all 7 cases included here.

In detailed databases of human brain transcriptomes, no difference in the transcribed protein between the 2 hemispheres of the brain was displayed, despite the well-known differences in functional organization between the dominant and nondominant hemispheres. ${ }^{3,12}$ This does not rule out posttranslational modifications to protein structure, and thus an antigenic basis for unilateral vasculitis remains possible. Also, no significant difference in total arterial supply between the 2 hemispheres exists according to the best available evidence. ${ }^{4}$ Granted, no immunologic study of the difference between the 2 cerebral hemispheres in arterial wall antigenic structure has been conducted. We did find that 2 of the 7 cases showed hemisphere asymmetry of arterial caliber size, although in 1 case, the diseased hemisphere showed smaller vessels, whereas the opposite was true in the other. Given that no consistent asymmetrical vessel distribution was seen by neuroimaging, it is unlikely that abnormal angiogenesis or a vascular endothelial growth factor-driven process is related to disease mechanisms in these cases. The lymphatic drainage system participates in immune responses and surveillance and could be associated with unilateral inflammation, but there is no current method to measure asymmetry of the lymphatic system. ${ }^{13}$ Some researchers advocate for a correlation between handedness and immune response, with reports of an increased tendency toward autoimmune disease ( 2.5 odds ratio) in left-handed individuals $^{14}$; however, there was no consistent relationship between the patient's dominant hand and the diseased side of the brain in these 7 cases with UR-PACNS.

Thus, it is more likely that intrinsic hemispheric asymmetries in immune reactivity between the right and left brain, rather than antigenic or structural differences, explain the puzzling unilaterality of disease in these cases. Interhemispheric discrepancies in basal levels of cytokines (e.g., interleukin 1 and interleukin 6), differences in modulation of immune function, and asymmetric distribution of microglia have been described in animal models. $^{15-20}$ In patients with Rasmussen encephalitis, schizophrenia, Creutzfeldt-Jakob disease, and Parkinson disease, interhemispheric differences in genomic and epigenomic states that regulate immune cell development, function, and signaling are implicated in lateralized hemispheric dysregulation. ${ }^{21-23}$ Lateralization of brain functional immune properties may have predisposed to asymmetric inflammatory responses in our patients, but this remains to be determined.

There is the possibility for overlap of UR-PACNS with Rasmussen encephalitis, although the European consensus diagnostic criteria for Rasmussen encephalitis require the exclusion of unihemispheric vasculitis. ${ }^{24}$ Indeed, case 1 and case 3 otherwise fulfill the diagnostic criteria. We note that the biopsy results for these cases most prominently suggest perivascular inflammation and do not demonstrate the typical microglial nodules seen with Rasmussen encephalitis. Furthermore, Rasmussen encephalitis commonly presents with seizures in childhood that progress to epilepsia partialis continua. It is possible, however, that Rasmussen encephalitis and UR-PACNS lie on a spectrum of related disorders especially as some Rasmussen biopsies have suggested dual pathology including perivascular lymphocytes. ${ }^{25}$ We also note here that anti-myelin oligodendrocyte glycoprotein encephalitis has been reported to mimic CNS vasculitis in histopathologic samples. ${ }^{26}$ Unfortunately, serum testing for this was not commercially available during the time frame of follow-up of these patients, and thus, this is a limitation to our report.

In patients with a high diagnostic suspicion of PACNS, we advocate for early brain biopsy. If an initial biopsy is nondiagnostic, and high suspicion remains, we advocate for a second targeted lesional biopsy during disease relapse, ideally including meninges, cortex, and white matter. Two of the 7 cases we reviewed here were diagnosed on the second brain biopsy. Based on current experience from this case series, early induction therapy with cyclophosphamide ( $15 \mathrm{mg} / \mathrm{kg}$ every 2 weeks for 3 doses and then every 3 weeks for 3-6 doses $)^{27,28}$ is advised, followed by maintenance therapy with a steroid sparing agent such as methotrexate (20-25 mg/wk) or mycophenolate $(1-2 \mathrm{mg} / \mathrm{kg}$ daily). Rituximab ( $375 \mathrm{mg} / \mathrm{m}^{2}$ once a week for 4 doses or $1,000 \mathrm{mg}$ twice, 2 weeks apart; each dose being successful in 1 of the 7 cases) in lieu of cyclophosphamide or as maintenance therapy is also favorable in many cases. ${ }^{28,29}$ In addition, a 3- to 5-day course of IV pulse glucocorticoid therapy during an acute relapse is recommended. Clinical and neuroimaging (brain MRI with contrast) follow-up should be performed once every 1-2 years or more frequently as needed.

\section{Study Funding}

No targeted funding reported.

\section{Disclosure}

M.A. AbdelRazek reports no conflict of interest. J.M. Hillis participates in research funded by GE Healthcare and is an investor in Elly Health. Y. Guo, M. Martinez-Lage, and T. Gholipour report no conflict of interest. J. Sloane has served on advisory boards for Biogen, Genentech, Celgene, EMD Serono, Teva, and Genzyme; he has grant funding from Biogen, Genentech, EMD Serono, and the National MS Society. T. Cho reports no conflict of interest. M. Matiello is an advisory board member for Alexion, Genentech, and VielaBio; he is funded by the Clinician-Teacher Development Award by the Mass General Hospital Center for Diversity and Inclusion. Go to Neurology.org/NN for full disclosures. 


\section{Publication History}

Received by Neurology: Neuroimmunology \& Neuroinflammation August 11, 2020. Accepted in final form October 22, 2020.

Appendix Authors

\begin{tabular}{lll}
\hline Name & Location & Contribution \\
\hline $\begin{array}{l}\text { Mahmoud A. } \\
\text { AbdelRazek, } \\
\text { MD }\end{array}$ & $\begin{array}{l}\text { Mount Auburn } \\
\text { Hospital, } \\
\text { Cambridge, MA }\end{array}$ & $\begin{array}{l}\text { Designed and conceptualized the } \\
\text { study; analyzed the data; } \\
\text { interpreted the data; and drafted } \\
\text { the manuscript }\end{array}$
\end{tabular}

\begin{tabular}{ll}
\hline James M. & Massachusetts \\
Hillis, MBBS & $\begin{array}{l}\text { General Hospital, } \\
\text { Boston }\end{array}$
\end{tabular}

Major role in drafting the manuscript for intellectual content and provided patient radiographic data

\begin{tabular}{ll}
\hline Yanjun Guo, & Beijing Tongren \\
MD & Hospital, China
\end{tabular}

Major role in drafting the manuscript for intellectual content and provided patient radiographic data

\begin{tabular}{ll}
\hline Maria & Massachusetts \\
Martinez- & General Hospital, \\
Lage, MD & Boston
\end{tabular}

Minor role in drafting the manuscript; revised the manuscript for intellectual content; and reviewed and provided pathology slides and commentary

\begin{tabular}{lll}
\hline $\begin{array}{l}\text { Taha } \\
\text { Gholipour, } \\
\text { MD }\end{array}$ & $\begin{array}{l}\text { The George } \\
\text { Washington } \\
\text { University, DC }\end{array}$ & $\begin{array}{l}\text { Revised the manuscript for } \\
\text { intellectual content }\end{array}$ \\
\hline $\begin{array}{l}\text { Jacob Sloane, } \\
\text { MD, PhD }\end{array}$ & $\begin{array}{l}\text { BIDMC, Boston, } \\
\text { MA }\end{array}$ & $\begin{array}{l}\text { Revised the manuscript for } \\
\text { intellectual content }\end{array}$ \\
\hline $\begin{array}{l}\text { Tracey Cho, } \\
\text { MD }\end{array}$ & University of lowa & $\begin{array}{l}\text { Revised the manuscript for } \\
\text { intellectual content }\end{array}$ \\
\hline $\begin{array}{l}\text { Marcelo } \\
\text { Matiello, MD }\end{array}$ & $\begin{array}{l}\text { Massachusetts } \\
\text { General Hospital, } \\
\text { Boston }\end{array}$ & $\begin{array}{l}\text { Study design; interpreted the data; } \\
\text { major role in revising the } \\
\text { manuscript for intellectual } \\
\text { content; and minor role in drafting } \\
\text { the manuscript }\end{array}$ \\
\hline
\end{tabular}

\section{References}

1. Cravioto H, Feigin I. Noninfectious granulomatous angiitis with a predilection for the nervous system. Neurology 1959;9:599-609. doi: 10.1212/wnl.9.9.599.

2. Salvarani C, Brown RD Jr, Christianson T, et al. An update of the Mayo Clinic cohort of patients with adult primary central nervous system vasculitis: description of 163 patients. Medicine 2015;94:e738. doi: 10.1097/MD.0000000000000738.

3. Hawrylycz MJ, Lein ES, Guillozet-Bongaarts AL, et al. An anatomically comprehensive atlas of the adult human brain transcriptome. Nature 2012;489:391-399. doi: 10 . 1038 /nature11405.

4. Burlakoti A, Kumaratilake J, Taylor J, Henneberg M. Asymmetries of total arterial supply of cerebral hemispheres do not exist. Heliyon 2019;5:e01086. doi: 10.1016/j.heliyon.2018. e01086.

5. de Boysson H, Zuber M, Naggara O, et al. Primary angiitis of the central nervous system: description of the first fifty-two adults enrolled in the French cohort of patients with primary vasculitis of the central nervous system. Arthritis Rheumatol 2014;66:1315-1326. doi: 10.1002/art.38340.
6. Derry C, Dale RC, Thom M, Miller DH, Giovannoni G. Unihemispheric cerebral vasculitis mimicking Rasmussen's encephalitis. Neurology 2002;58:327-328. doi: 10. 1212/wnl.58.2.327.

7. Damasceno A, Franca M Jr, Queiroz LS, Cendes F, Nucci A, Damasceno BP. Adult onset chronic unihemispheric vasculitis resembling Rasmussen encephalitis. Neurologist 2009;15:285-288. doi: 10.1097/NRL.0b013e31818fc74e.

8. Ho MG, Chai W, Vinters HV, et al. Unilateral hemispheric primary angiitis of the central nervous system. J Neurol 2011;2589:1714-1716. doi: 10.1007/s00415-0115993-1.

9. Johnson MA, Jakubek GA, Hawley JS. Unihemispheric cerebral vasculitis: case report and review of literature. J Neurol Sci 2016;368:32-34. doi: 10.1016/j.jns.2016.06.049.

10. Braun KP, Bulder MM, Chabrier S, et al. The course and outcome of unilateral intracranial arteriopathy in 79 children with ischaemic stroke. Brain 2009;132: 544-557. doi: 10.1093/brain/awn313.

11. Bulder MM, Braun KP, Leeuwis JW, et al. The course of unilateral intracranial arteriopathy in young adults with arterial ischemic stroke. Stroke 2012;43:1890-1896. doi: 10.1161/STROKEAHA.112.653212.

12. Johnson MB, Kawasawa YI, Mason CE, et al. Functional and evolutionary insights into human brain development through global transcriptome analysis. Neuron 2009;62: 494-509. doi: 10.1016/j.neuron.2009.03.027.

13. Louveau A, Smirnov I, Keyes TJ, et al. Structural and functional features of central nervous system lymphatic vessels. Nature 2015;523:337-341. doi: 10.1038/nature14432.

14. Geschwind N, Behan P. Left-handedness: association with immune disease, migraine, and developmental learning disorder. Proc Natl Acad Sci USA 1982;79:5097-5100. doi: $10.1073 /$ pnas.79.16.5097.

15. Neveu PJ. Asymmetrical brain modulation of the immune response. Brain Res Brain Res Rev 1992;17:101-107. doi: 10.1016/0165-0173(92)90010-j.

16. Neveu PJ. Cerebral lateralization and the immune system. Int Rev Neurobiol 2002;52: 303-323. doi: 10.1016/s0074-7742(02)52014-6.

17. Fu QL, Shen YQ, Gao MX, Dong J, Neveu PJ, Li KS. Brain interleukin asymmetries and paw preference in mice. Neuroscience 2003;116:639-647. doi: 10.1016/s03064522(02)00746-7.

18. Meador KJ, Loring DW, Ray PG, Helman SW, Vazquez BR, Neveu PJ. Role of cerebral lateralization in control of immune processes in humans. Ann Neurol 2004; 55:840-844. doi: 10.1002/ana.20105.

19. Shen YQ, Hebert G, Lin LY, et al. Interleukine-1beta and interleukine-6 levels in striatum and other brain structures after MPTP treatment: influence of behavioral lateralization. J Neuroimmunol 2005;158:14-25. doi: 10.1016/j.jneuroim.2004.06.011.

20. Shen YQ, Hébert G, Moze E, Li KS, Neveu PJ. Asymmetrical distribution of brain interleukin-6 depends on lateralization in mice. Neuroimmunomodulation 2005;12: 189-194. doi: 10.1159/000084852.

21. Steiner J, Mawrin C, Ziegeler A, et al. Distribution of HLA-DR-positive microglia in schizophrenia reflects impaired cerebral lateralization. Acta Neuropathol 2006;112: 305-316. doi: 10.1007/s00401-006-0090-8.

22. Wu HM, Lu CS, Huang CC, et al. Asymmetric involvement in sporadic CreutzfeldtJakob disease: clinical, brain imaging, and electroencephalographic studies. Eur Neurol 2010;64:74-79. doi: 10.1159/000315148.

23. Li P, Ensink E, Lang S, et al. Hemispheric asymmetry in the human brain and in Parkinson's disease is linked to divergent epigenetic patterns in neurons. Genome Biol 2020;21:61. doi: 10.1186/s13059-020-01960-1.

24. Bien CG, Granata T, Antozzi C, et al. Pathogenesis, diagnosis and treatment of Rasmussen encephalitis: a European consensus statement. Brain 2005;128(pt 3): 454-471. doi: 10.1093/brain/awh415.

25. Hart YM, Andermann F, Robitaille Y, Laxer KD, Rasmussen T, Davis R. Double pathology in Rasmussen's syndrome: a window on the etiology? Neurology 1998;50: 731-735. doi: 10.1212/wnl.50.3.731.

26. Patterson K, Iglesias E, Nasrallah M, et al. Anti-MOG encephalitis mimicking small vessel CNS vasculitis. Neurol Neuroimmunol Neuroinflamm 2019;6:e538. doi: 10. 1212/NXI.0000000000000538.

27. de Groot K, Harper L, Jayne DR, et al. Pulse versus daily oral cyclophosphamide for induction of remission in antineutrophil cytoplasmic antibody-associated vasculitis: a randomized trial. Ann Intern Med 2009; 150:670-680. doi: 10.7326/0003-4819-15010-200905190-00004.

28. Mukhtyar C, Guillevin L, Cid MC, et al. EULAR recommendations for the management of primary small and medium vessel vasculitis. Ann Rheum Dis 2009;68: 310-317. doi: 10.1136/ard.2008.088096.

29. Stone JH, Merkel PA, Spiera R, et al. Rituximab versus cyclophosphamide for ANCAassociated vasculitis. N Engl J Med 2010;363:221-232. doi: 10.1056/ NEJMoa0909905. 


\section{Neurology ${ }^{\oplus}$ \\ Neuroimmunology \& Neuroinflammation}

Unilateral Relapsing Primary Angiitis of the CNS: An Entity Suggesting Differences in the Immune Response Between the Cerebral Hemispheres

Mahmoud A. AbdelRazek, James M. Hillis, Yanjun Guo, et al.

Neurol Neuroimmunol Neuroinflamm 2021;8;

DOI 10.1212/NXI.0000000000000936

This information is current as of January 5, 2021

Neurol Neuroimmunol Neuroinflamm is an official journal of the American Academy of Neurology.

Published since April 2014, it is an open-access, online-only, continuous publication journal. Copyright

Copyright $\odot 2021$ The Author(s). Published by Wolters Kluwer Health, Inc. on behalf of the American

Academy of Neurology.. All rights reserved. Online ISSN: 2332-7812.

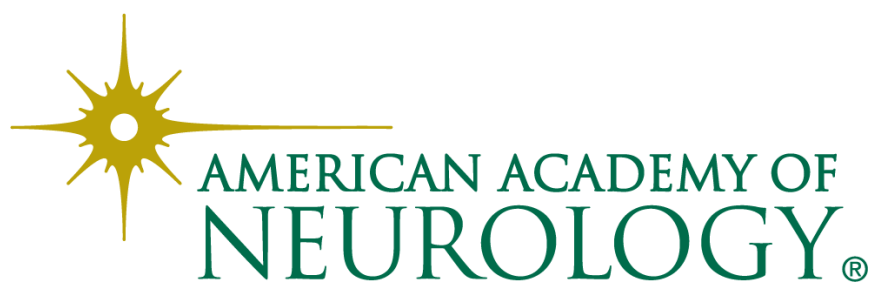




\section{Updated Information \& Services}

References

Citations

Subspecialty Collections

Permissions \& Licensing

Reprints including high resolution figures, can be found at: http://nn.neurology.org/content/8/2/e936.full.html

This article cites 29 articles, 4 of which you can access for free at: http://nn.neurology.org/content/8/2/e936.full.html\#\#ref-list-1

This article has been cited by 1 HighWire-hosted articles: http://nn.neurology.org/content/8/2/e936.full.html\#\#otherarticles

This article, along with others on similar topics, appears in the following collection(s):

All Immunology

http://nn.neurology.org//cgi/collection/all_immunology

Autoimmune diseases

http://nn.neurology.org//cgi/collection/autoimmune_diseases

Infarction

http://nn.neurology.org//cgi/collection/infarction

Vasculitis

http://nn.neurology.org//cgi/collection/vasculitis

Information about reproducing this article in parts (figures,tables) or in its entirety can be found online at:

http://nn.neurology.org/misc/about.xhtml\#permissions

Information about ordering reprints can be found online:

http://nn.neurology.org/misc/addir.xhtml\#reprintsus

Neurol Neuroimmunol Neuroinflamm is an official journal of the American Academy of Neurology.

Published since April 2014, it is an open-access, online-only, continuous publication journal. Copyright

Copyright $\odot 2021$ The Author(s). Published by Wolters Kluwer Health, Inc. on behalf of the American

Academy of Neurology.. All rights reserved. Online ISSN: 2332-7812.

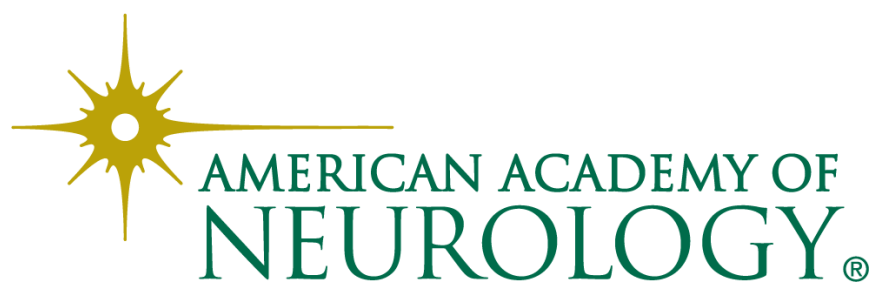

